\title{
An Influence of Slag Refining on the Structure and Mechanical Properties of the Brass CuZn39Pb2
}

Mariusz Jenek ( $\Delta$ m.jenek@iim.uz.zgora.pl )

University of Zielona Gora: Uniwersytet Zielonogorski https://orcid.org/0000-0001-8310-3678

Paweł Shlafka

\section{Research Article}

Keywords: refining, structure, mechanical properties, brass

Posted Date: February 10th, 2021

DOI: https://doi.org/10.21203/rs.3.rs-182111/v1

License: (1) This work is licensed under a Creative Commons Attribution 4.0 International License. Read Full License 


\section{Abstract}

The results presented in the dissertation show the influence of a kind and concentration of the flux added during the process of the lead brass smelting on its structure, chemical composition and mechanical properties - hardness and strength. A positive i refining, structure, mechanical properties, brassnfluence of the refining and modification process manifested in an improvement of mechanical properties as well as an increase of the structure, chemical composition and mechanical properties homogeneity in the entire volume of the ingot has been proven.

\section{Introduction}

Due to its properties (malleability, ductility, corrosion resistance), brass is one of the most common alloys. Brass and its alloys belong to materials which can be recovered from recyclable resources (production wastes, scrap). Depending on the level of the copper scrap purity and its chemical composition dependability, it can be smelted directly or it must be refined and modified during the smelting process [19PS]. The refining aims at eliminating the unfavourable additions and, as a result, at the improvement of mechanical properties. Nowadays, the refining and modification play the key role in the processes of manufacturing metals and alloys with high mechanical properties [1-5].

Modifying metals and their alloys with microadditions of selected elements enables a positive impact on a primary structure of alloys made in a process of solidification. The studies of the authors $[1,6,7]$ have shown a significant complexity of the brass alloys modification processes. On account of the environmental protection $[1,5,7]$, to reduce the amount of harmful substances emerged in the refining and modification process, an attempt to intensify the impact of chemical substances on an alloy by their appropriate selection should be made $[1,5]$.

\section{Research Methodology}

In the research, the copper CuZn39Pb2 has been used. Its chemical composition, in accordance to the standard, has been presented in table 1 .

Table 1 Chemical composition the brass CuZn39Pb2

\begin{tabular}{|llllllll|}
\hline Chemical element & $\mathrm{Cu}$ & $\mathrm{Al}$ & $\mathrm{Fe}$ & $\mathrm{Ni}$ & $\mathrm{Sn}$ & $\mathrm{Pb}$ & $\mathrm{Zn}$ \\
\hline Contents & $59-60$ & $<0.05$ & $<0.3$ & $<0.3$ & $<0.3$ & $1.6-2.5$ & rest \\
{$[\%]$} & & & & & & & \\
\hline
\end{tabular}

In the research, the Topbal Z flux has been used. There have been three smelts corresponding to the concentration:

- without any flux 
- $1 \%$ of the kiln charge

- $15 \%$ of the kiln charge

The smelting has been proceeded in industrial conditions in Radne 1500 coreless induction furnace. The feedstock was the process scrap from the material removal processing, containing the cooling lubricant. The single kiln charge was $1200 \mathrm{~kg}$.

The places in the smelt where the samples for the research have been cut out from have been presented in Fig.1.

The structure of prepared microsections has been examined by an optical microscope AXIO Observer A1 $\mathrm{m}$ in six zones with zooms 50-1000x. The quantitative and qualitative research has been done on the scanning microscope JSM-5600LV by JOEL, equipped with a EDS 2000 X-ray analyser by IXRF SYSTEMS.

The strength tests of samples from the particular smelts have been done on a fatigue testing system INSTRON 8802, on samples cast to die casting moulds. Hardness of particular samples has been determined on the Zwick/Roel ZHV10 hardness tester with load of $200 \mathrm{~g}$.

\section{The Research Results}

The research of the refining influence on the brass structure has given the results shown in fig. 2, illustrated by examples of selected images of chosen zones. The microstructure consists of the solid solution $\alpha$, phase $\beta^{\prime}$ and lead removals.

The research of the refining influence on the brass structure has given the results shown in fig. 2, illustrated by examples of selected images of chosen zones. The microstructure consists of the solid solution a, phase $\beta^{\prime}$ and lead removals.

Analysing the photos in the table it can be noticed that the refining process has an impact on a microstructure of the brass CuZn39Pb2 such as changes in a size of solid solution a removals, phase $\beta^{\prime}$ and a removals size as well as the arrangement of the lead. Using Topbal $Z$ flux in the refining process results in the structure homogenisation.

Visible changes of the microstructure can be observed for the zone 2 ( $0.15 \%$ Topbal Z) whereas in zones 3-6 the structure is homogenous (anisotropic crystals). On the observed metallographic microsections it may be noticed that the solid solution a removals and phases $\beta^{\prime}$ have mixed. The lead removals are seen as tiny and dark, arranged evenly in the entire volume of the analysed zones, not creating clusters on the border of the solid solution $a$ and phase $\beta^{\prime}$. In the alloy which has not been refined there are lead removals creating clusters on the border of the solid solution $a$ and phase $\beta^{\prime}$, which has a negative impact on the mechanical properties of the alloy. The growth of the flux concentration influences the increase of the frozen crystals layer's volume, which significantly increases the hardness of the surface layer. 
The analysis of the chemical composition the samples has been presented in the fig. $3-11$.

The percentage difference in the basic alloy elements for particular smelts, for the samples from different areas of the ingot, has been presented in the fig. 12-14.

As shown in the pictures above, the alloy refining contributed to the increase of the chemical composition stability in the entire volume of the ingot. The closest to the normative and the most stable chemical composition has been reached for the flux added to the smelt in the concentration of $0.15 \%$.

The hardness of the particular samples has been measured and the results have been shown in the fig. 15.

As seen in Fig. 15, in the zone 1 there is an essential difference in the hardness of the samples from different smelts. The highest hardness in this zone, discovered in the sample cast without the flux, was caused by the increased thickness of the frozen crystals zone. The increased hardness in the zone of the casting skin (the surface zone of the cast), can result, in case of mechanical processing, in a faster cutting tool wear. In the rest of the zones considered, the hardness values have not shown any significant differences.

The results of the strength tests have been presented in the fig. 16.

On the basis of the data received by the tensile testing it may be stated that materials emerged in the refining process are characterised by higher strength parameters. The differences in the parameters of the strength properties for the samples from the smelting with the use of the flux are insignificant. However, they are noticeably higher than parameters for the sample created without any modification.

\section{Conclusions}

As a conclusion from the research done, what must be highlighted, is the significant and positive impact of the Topbal Z flux on the refining process and receivedmetallographic structures, characterised by higher homogeneity and grain refinement. The refining contributed also to an improvement of mechanical properties by increasing the strength of the alloys received as a result of the refining. Taking the further alloys mechanical processing into consideration, modifying the alloy with the flux concentration $0.1 \%$ of the kiln charge has proven to be the most favourable. The surface layer expansion, characterised by higher hardness which may result in the increased cutting tool wear, has not been observed at this concentration.

\section{Declarations}

Author contribution Paweł Shlafka: Conceptualization, Methodology, Investigation, Formal analysis, Writing - Original Draft, Writing - Review \& Editing, Visualization. Mariusz Jenek: Writing - Review \& Editing, Supervision. 
Compliance with ethical standards All authors certify that they have no affiliations with or involvement in any organization or entity with any financial interest or non-financial interest in the subject matter or materials discussed in this manuscript. The authors give their consent for publication.

Competing interests The authors declare that they have no competing interests.

Funding M.R.D., K.K.D., W.W. acknowledge the financial support from the program of the Polish Minister of Science and Higher Education under the name "Regional Initiative of Excellence" in 2019 - 2022, project no. 003/RID/2018/19

Consent to participate Not applicable.

Consent to publish Not applicable.

Availability of data and material Not applicable

\section{References}

1. A.W Bydałek.: Próba analizowania zdolności rafinacyjnych reduktora w warunkach topienia mosiądzów. Arch Technologii Maszyn i Automatyzacji, vol. 12., 1993, p.7

2. M. Kondracki, J. Gawrońsk, J. Szajnar, R. Grzelczak, K. Podsiadł, badanie procesu krystalizacji mosiądzu ołowiowego Mo59 przy pomocy ATD, Archives of Foundry, Year 2002, Volume 2, № 4, Nr 4 PAN - Katowice.

3. A.W. Bydatek, A. Bydałek (2014). The results of the brass refining process in the reducer conditions. Archives of Foundry Engineering 14(1), 21 - 24.

4. S. Rzadkosz, J. Zych, A. Garbacz-Klempka, M. Kranc, J. Kozana, M. Piękoś, J. Kolczyk, Ł. Jamrozowicz. (2015). Copper alloys in investment casting technology. Metalurgija. 54(1), 293-296.

5. P. Schlafka, A.W. Bydałek, M. Holtzer, W. Wołczyński. (2016). The Influence Of The lonic reactions On The Refining Secondary Raw Materials; Metalurgija, 55(4), 609-612.

6. F. Romankiewicz, Modyfikacja miedzi i jej niektórych stopów w warunkach procesu metalurgicznego, Monografia nr 20, WSI Zielona Góra 1983.

7. F. Romankiewicz, Modyfikacja miedzi i jej stopów, Komisja Nauki o Materiałach PAN Oddział w Poznaniu, Politechnika Zielonogórska, Zielona Góra 2000.

\section{Figures}




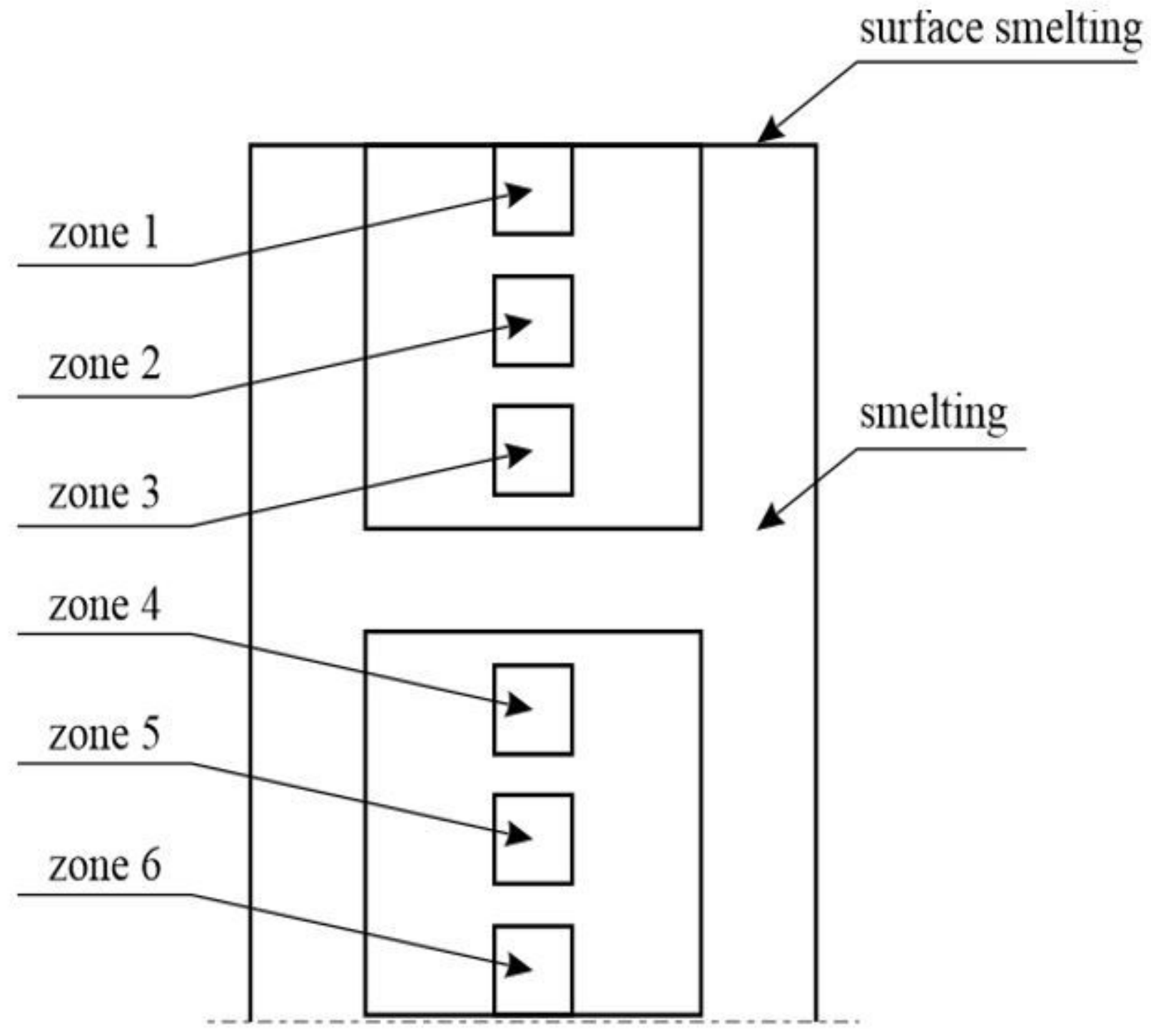

Figure 1

Places of taking samples from the smelt 


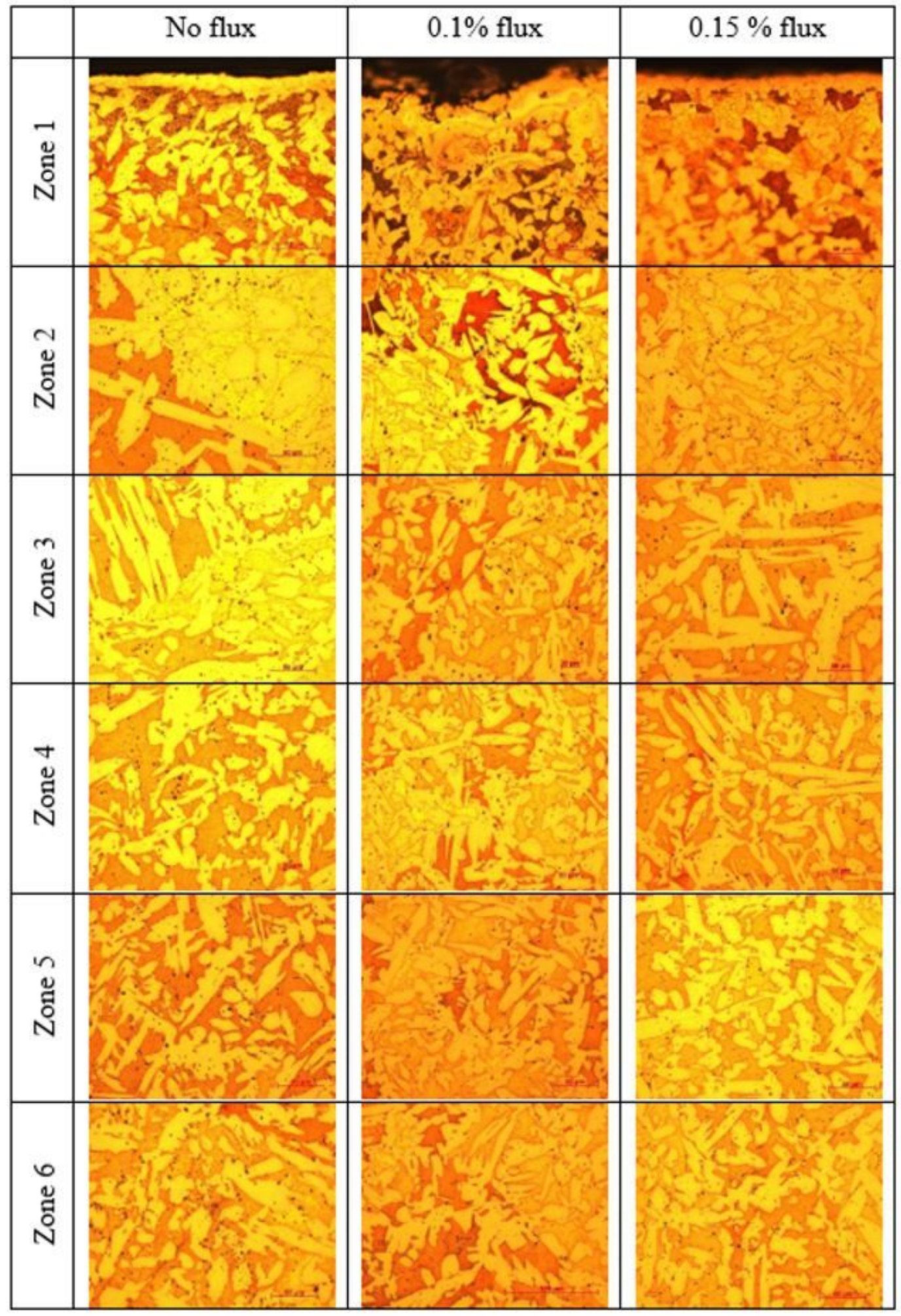

Figure 2

The metallographic structures of the samples in the selected zones (chemical etching of $\mathrm{Mi} 18 \mathrm{Cu}$ ) 


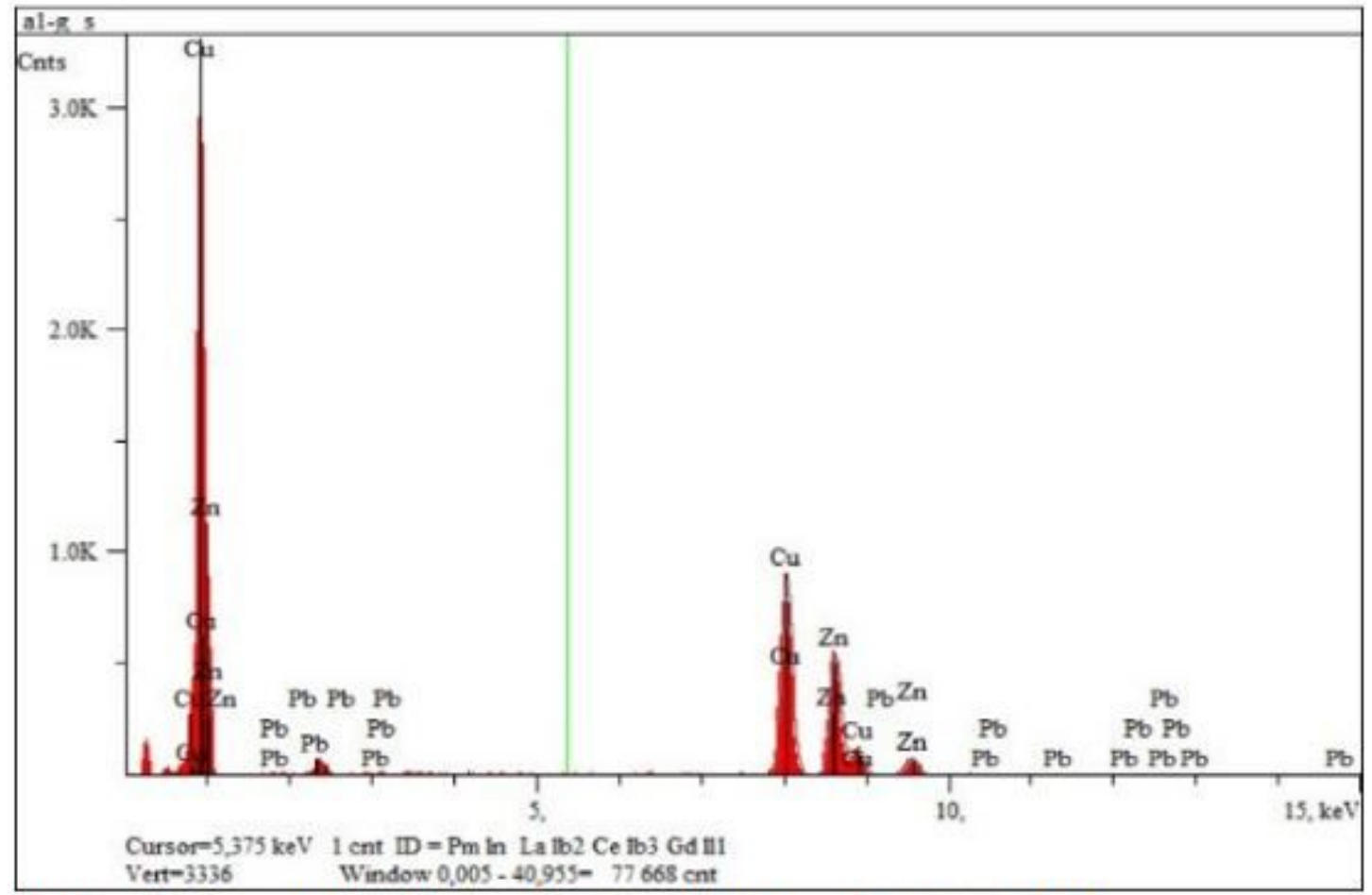

$\begin{array}{cc}\text { Elt. Line Intensity Conc Units } & \begin{array}{c}\text { Error } \\ (\mathrm{c} / \mathrm{s})\end{array} \\ 2 \text {-sig } & \begin{array}{r}\mathrm{MDL} \\ 3-\mathrm{sig}\end{array}\end{array}$

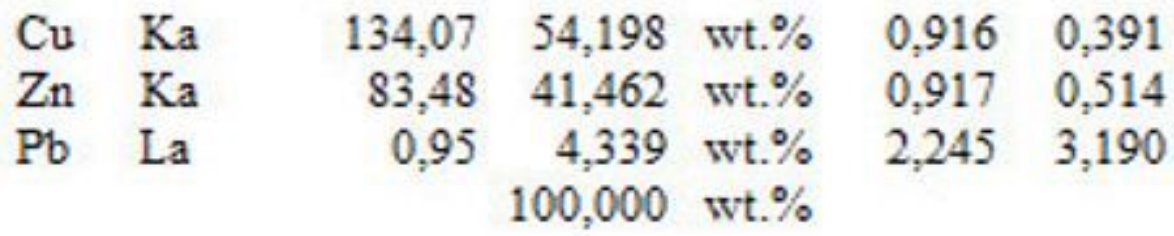

$\mathrm{kV} \quad 20,0$

Takeoff Angle $35,0^{\circ}$

Elapsed Livetime 113,1

Figure 3

Analysis of the chemical composition of the sample from smelt without flux, zone 1 


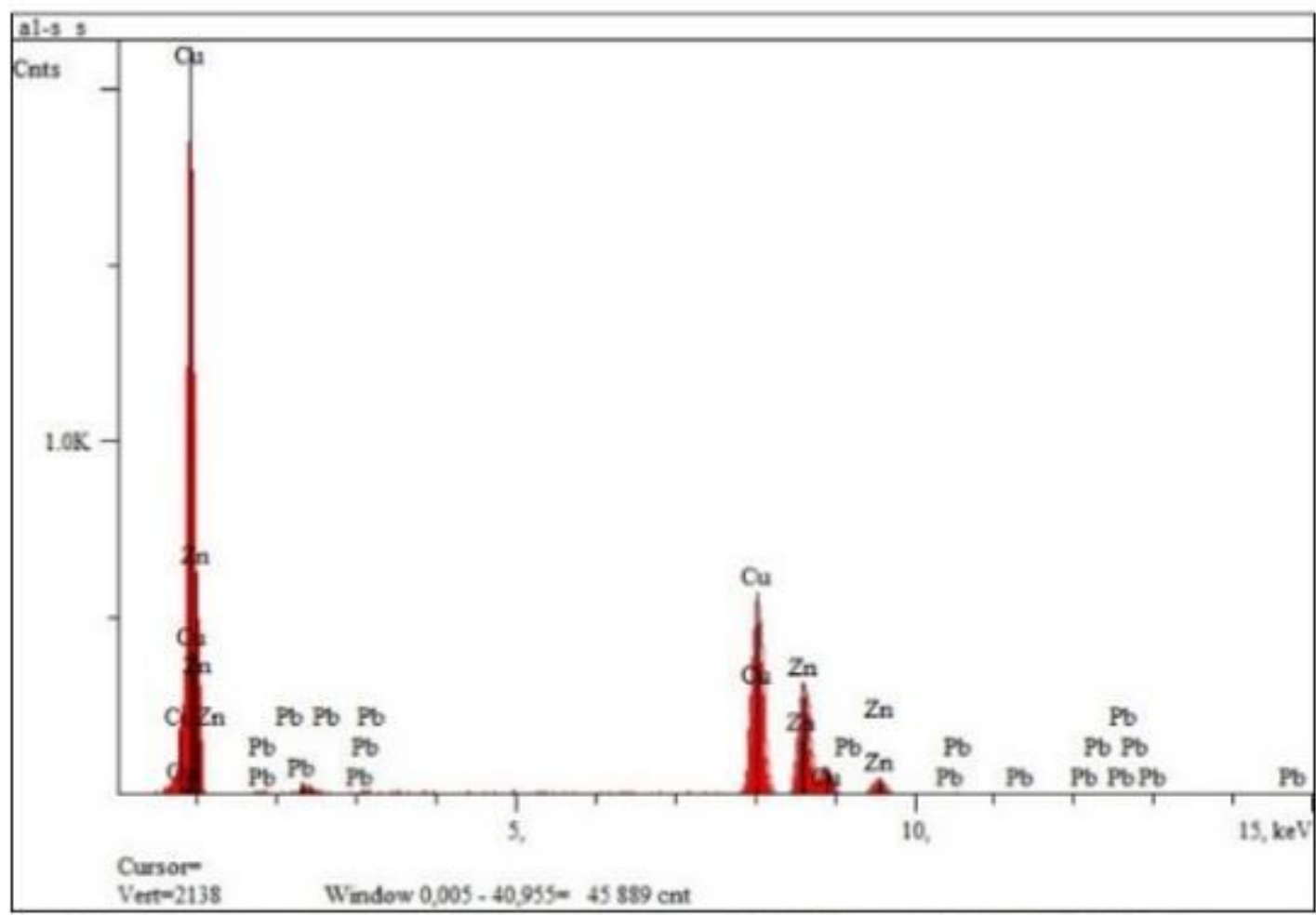

Elt. Line Intensity Conc Units Error MDL $(\mathrm{c} / \mathrm{s})$

2-sig 3-sig

$\begin{array}{lllllll}\mathrm{Cu} & \mathrm{Ka} & 155,30 & 56,925 & \text { wt. } \% & 1,224 & 0,522\end{array}$

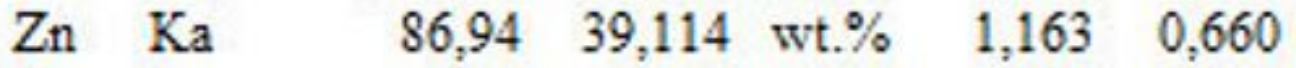

$\mathrm{Pb} \quad \mathrm{La} \quad 0,96 \quad 3,961 \quad$ wt. $\% \quad 2,851 \quad 4,063$

100,000 wt. $\%$

$\mathrm{kV} \quad 20,0$

Takeoff Angle $35,0^{\circ}$

Elapsed Livetime 60,4

Figure 4

Analysis of the chemical composition of the sample from smelt without flux, zone 2 


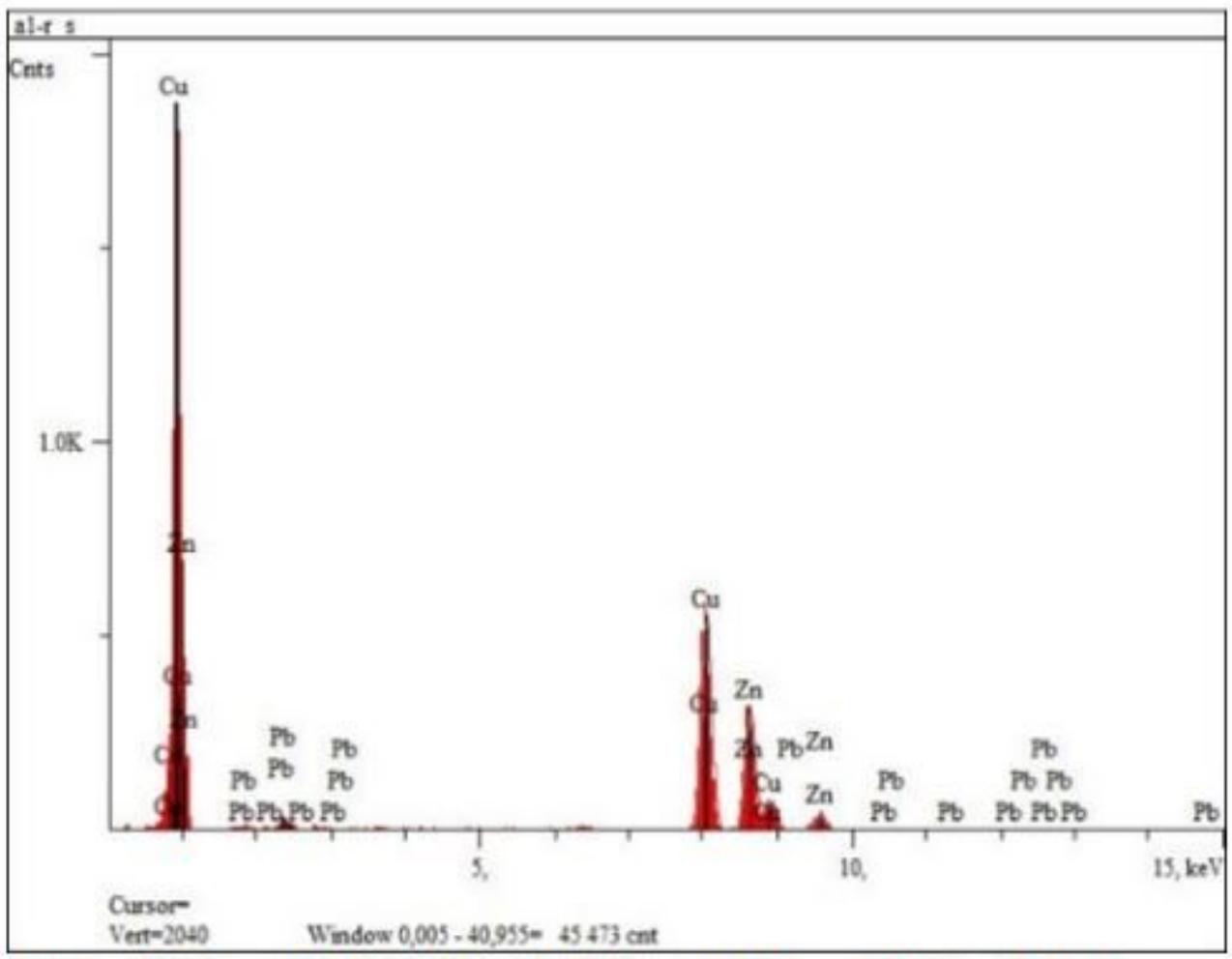

Elt. Line Intensity Conc Units Error MDL $(\mathrm{c} / \mathrm{s})$ 2-sig 3-sig

$\begin{array}{lllllll}\mathrm{Cu} & \mathrm{Ka} & 155,08 & 56,919 & \text { wt. } \% & 1,222 & 0,512\end{array}$ $\begin{array}{lllllll}\mathrm{Zn} & \mathrm{Ka} & 88,76 & 40,008 & \text { wt. } \% & 1,170 & 0,644\end{array}$ $\mathrm{Pb} \quad \mathrm{La} \quad 0,74 \quad 3,073 \quad$ wt. $\% \quad 2,675 \quad 3,846$ 100,000 wt. $\%$

$\mathrm{kV} \quad 20,0$

Takeoff Angle $35,0^{\circ}$

Elapsed Livetime 60,5

Figure 5

Analysis of the chemical composition of the sample from smelt without flux, zone 3 


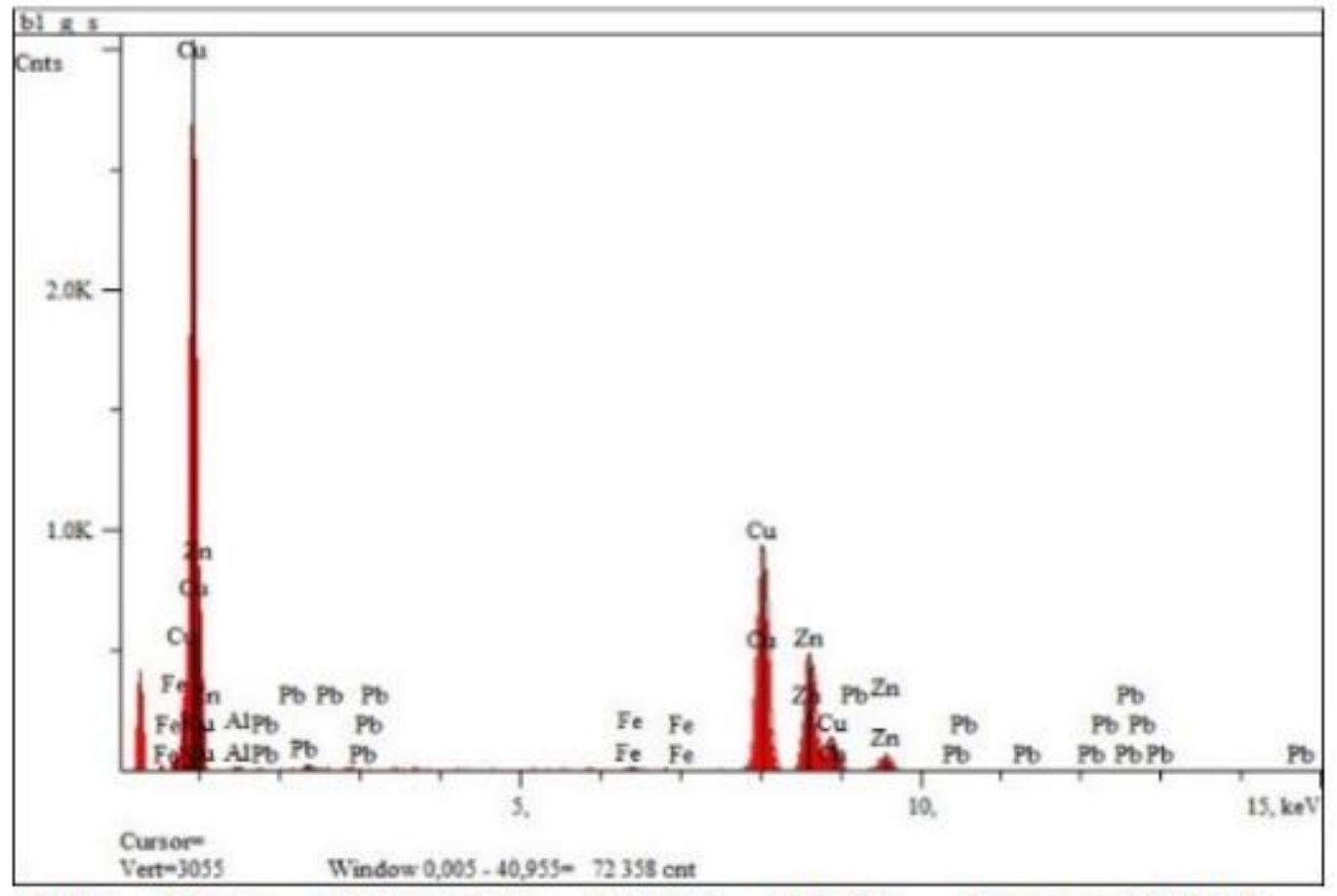

E1t. Line Intensity Conc Units Error MDL

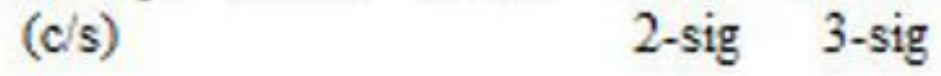
Al $\mathrm{Ka}$
1,66
0,429 wt. $\%$
$0,155 \quad 0,218$
$\mathrm{Fe} \mathrm{Ka}$
2,34
0,400 wt. $\%$
$0,115 \quad 0,161$
$\mathrm{Cu} \mathrm{Ka}$
132,17
58,667 wwt. $\%$
0,966
0,389
$\mathrm{Zn} \quad \mathrm{Ka}$
$67,94 \quad 36,976$ wt. $\%$
0,870
0,449
$\mathrm{Pb} \quad \mathrm{La}$
0,71
3,529 wt. $\%$
$2,165 \quad 3,099$
100,000 wt. $\%$

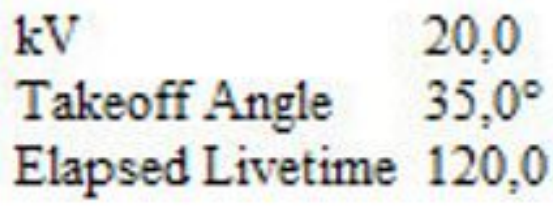

\section{Figure 6}

Analysis of the chemical composition of the sample from smelt $0.1 \%$ flux, zone 1 


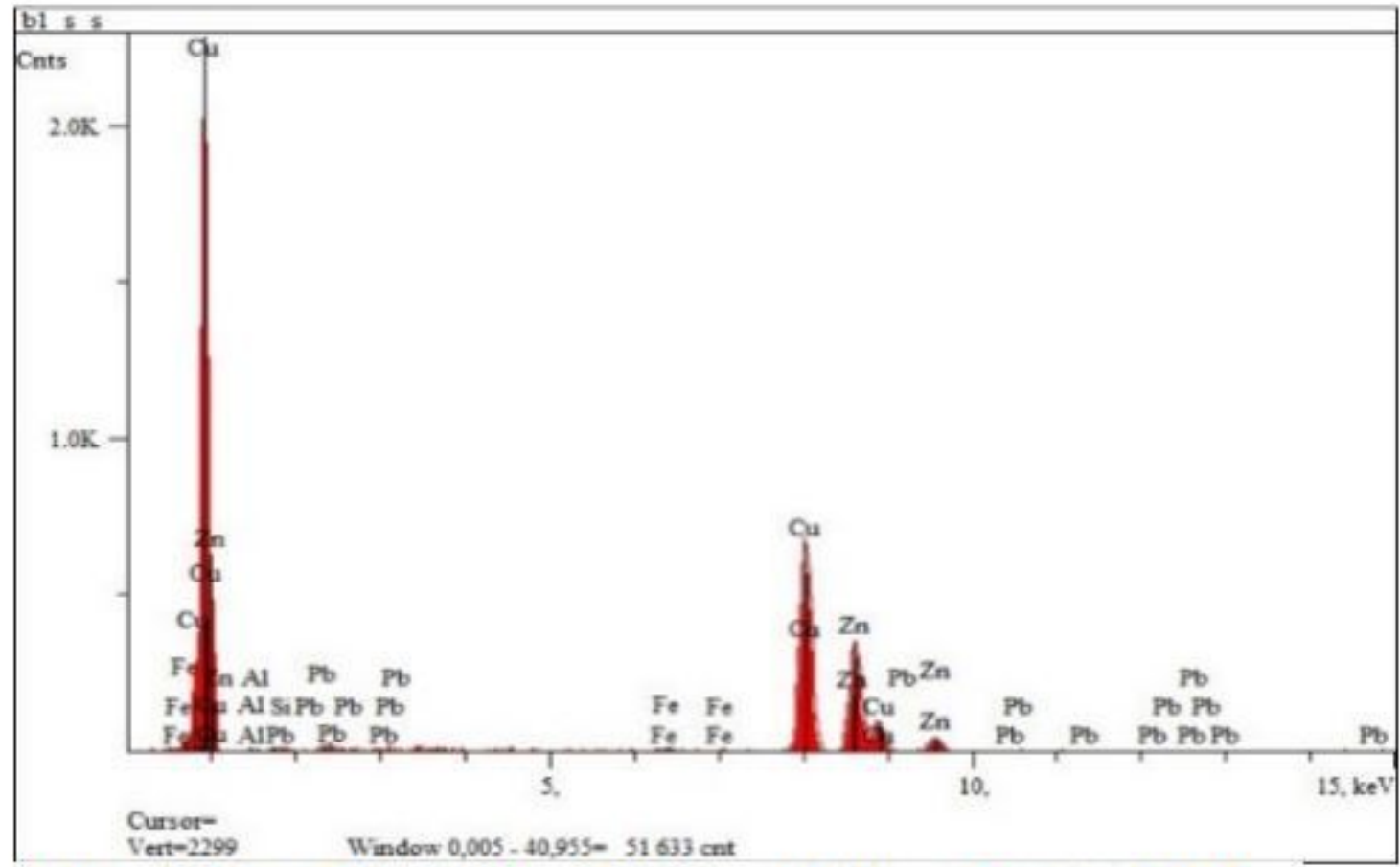

E1t. Line Intensity Conc Units Error MDL (c/s) 2-sig 3-sig

\begin{tabular}{|c|c|c|c|c|c|}
\hline $\mathrm{Ka}$ & 1,75 & 0,350 & wt. \% & 0,178 & 0,253 \\
\hline $\mathrm{Ka}$ & 2,58 & 0,401 & wt.\% & 0,149 & 0,207 \\
\hline $\mathrm{Ka}$ & 3,35 & 0,444 & wt.\% & 0,139 & 0,192 \\
\hline $\mathrm{Ka}$ & 172,52 & 59,190 & wt.\% & 1,165 & 0,48 \\
\hline $\mathrm{Ka}$ & 87,91 & 36,987 & wt.\% & 1,059 & 0,605 \\
\hline $\mathrm{La}$ & 0,68 & $\begin{array}{r}2,628 \\
100,000\end{array}$ & $\begin{array}{l}\text { wt. } \% \\
\text { wt. } \%\end{array}$ & 2,576 & 3,751 \\
\hline
\end{tabular}

$\mathrm{kV} \quad 20,0$

Takeoff Angle $\quad 35,0^{\circ}$

Elapsed Livetime 64,5

Figure 7

Analysis of the chemical composition of the sample from smelt $0.1 \%$ flux, zone 2 


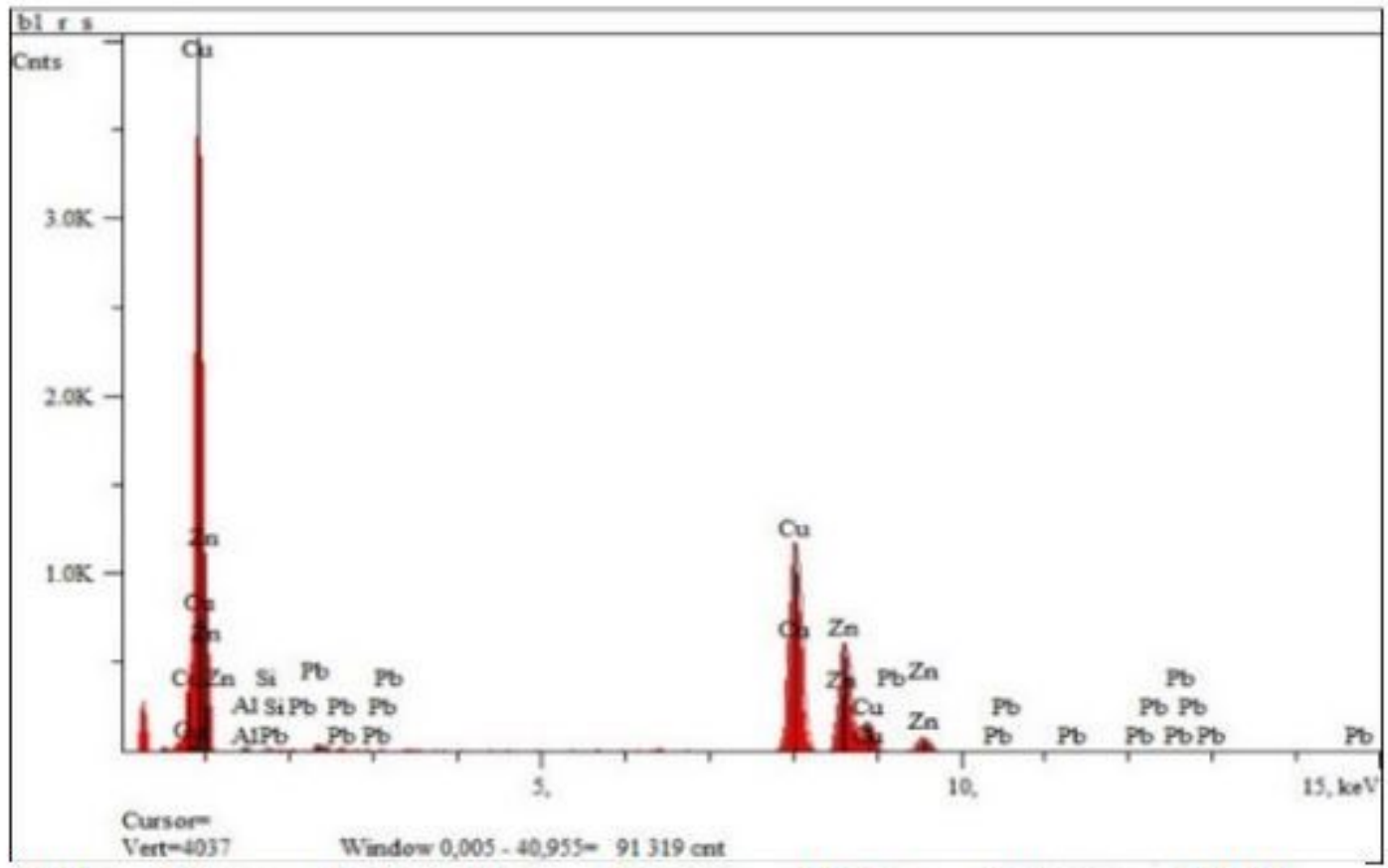

E1t. Line Intensity Conc Units Error MDL

(c/s) 2-sig 3-sig

$\begin{array}{llrrrrr}\text { Al } & \mathrm{Ka} & 2,29 & 0,472 & \text { wt. } \% & 0,135 & 0,187 \\ \mathrm{Si} & \mathrm{Ka} & 1,92 & 0,308 & \text { wt. } \% & 0,112 & 0,159 \\ \mathrm{Cu} & \mathrm{Ka} & 166,10 & 58,932 & \text { wt. } \% & 0,867 & 0,356 \\ \mathrm{Zn} & \mathrm{Ka} & 84,73 & 36,863 & \text { wt. } \% & 0,782 & 0,425 \\ \mathrm{~Pb} & \mathrm{La} & 0,86 & 3,426 & \text { wt. } \% & 1,954 & 2,807 \\ & & & 100,000 & \text { wt. } \% & & \end{array}$

$\mathrm{kV} \quad 20,0$

Takeoff Angle $\quad 35,0^{\circ}$

Elapsed Livetime 120,0

Figure 8

Analysis of the chemical composition of the sample from smelt $0.1 \%$ flux, zone 3 


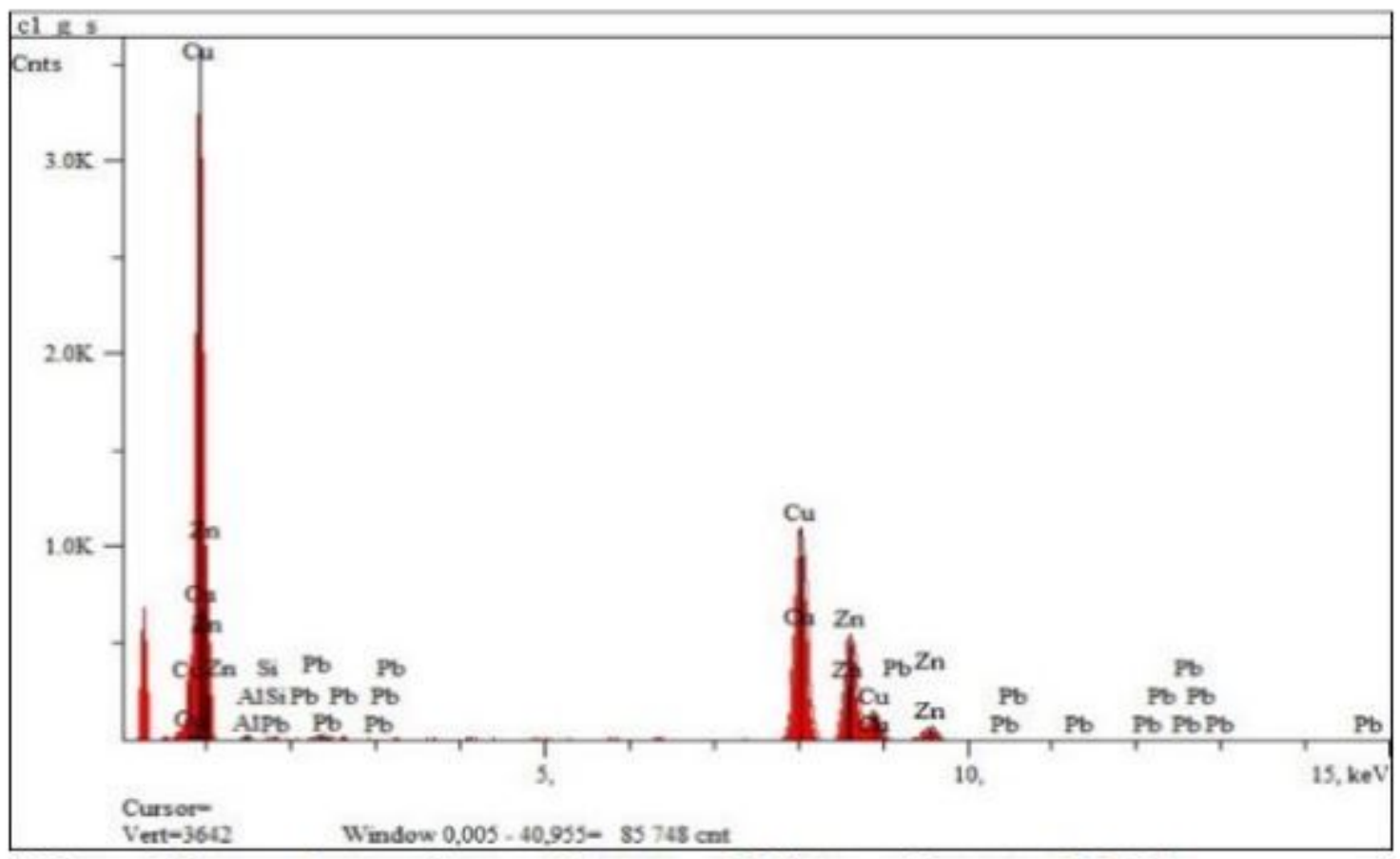

$\begin{array}{ccccc}\text { Elt. Line Intensity Conc Units } \begin{array}{c}\text { Error } \\ \text { 2-sig }\end{array} & \begin{array}{c}\mathrm{MDL} \\ 3 \text {-sig }\end{array}\end{array}$

$\begin{array}{llrrrrrr}\mathrm{A} 1 & \mathrm{Ka} & & 2,68 & 0,605 & \text { wt.\% } & 0,148 & 0,202 \\ \mathrm{Si} & \mathrm{Ka} & 1,36 & 0,240 & \text { wt. \% } & 0,120 & 0,174 \\ \mathrm{Cu} & \mathrm{Ka} & 153,07 & 59,371 & \text { wt. } \% & 0,909 & 0,371 \\ \mathrm{Zn} & \mathrm{Ka} & 77,31 & 36,773 & \text { wt. } \% & 0,819 & 0,453 \\ \mathrm{~Pb} & \mathrm{La} & 0,69 & 3,011 & \text { wt. } \% & 2,052 & 2,972 \\ & & & & 100,000 & \text { wt.\% } & & \end{array}$

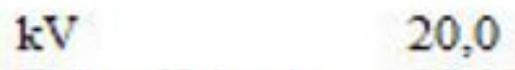

Takeoff Angle $\quad 35,0^{\circ}$

Elapsed Livetime 120,0

Figure 9

Analysis of the chemical composition of the sample from smelt $0.15 \%$ flux, zone 1 


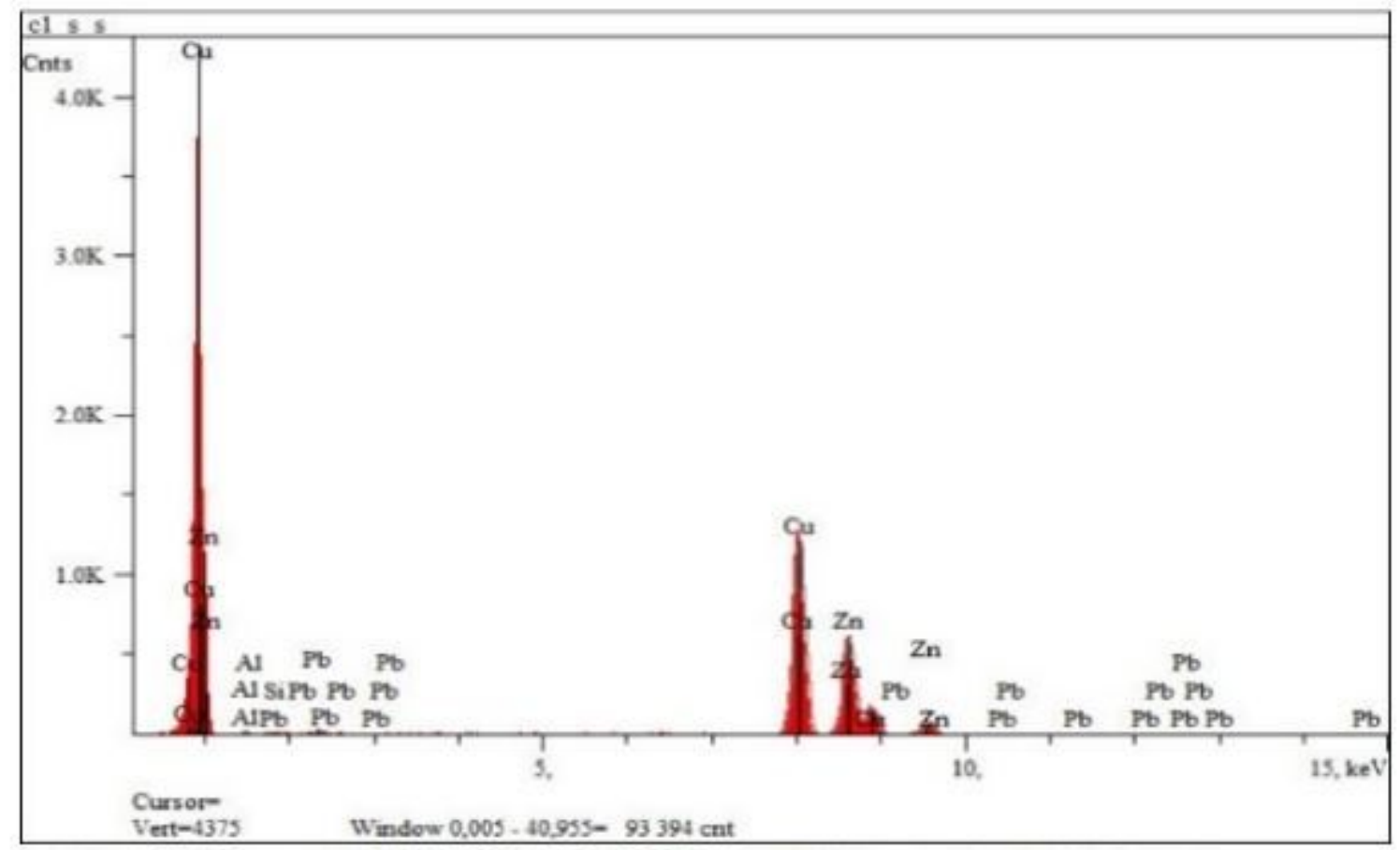

E1t. Line Intensity Conc Units Error MDL (c/s) 2-sig 3-sig
Al $\mathrm{Ka}$
1,96
0,395 wt. $\%$
$0,131 \quad 0,184$
$\mathrm{Si} \mathrm{Ka}$
$1,29 \quad 0,201$ wt. \%
0,107
0,156
$\mathrm{Cu} \mathrm{Ka}$
172,16
59,188 wt. $\%$
$0,855 \quad 0,350$
$\mathrm{Zn} \quad \mathrm{Ka}$
89,33
37,679 wt. $\%$
0,773
0,398
$\mathrm{Pb} \quad \mathrm{La}$
0,66
2,537 wt. $\%$
$1,859 \quad 2,707$
100,000 wt. $\%$

$\mathrm{kV} \quad 20,0$

Takeoff Angle $35,0^{\circ}$

Elapsed Livetime 120,0

Figure 10

Analysis of the chemical composition of the sample from smelt $0.15 \%$ flux, zone 2 


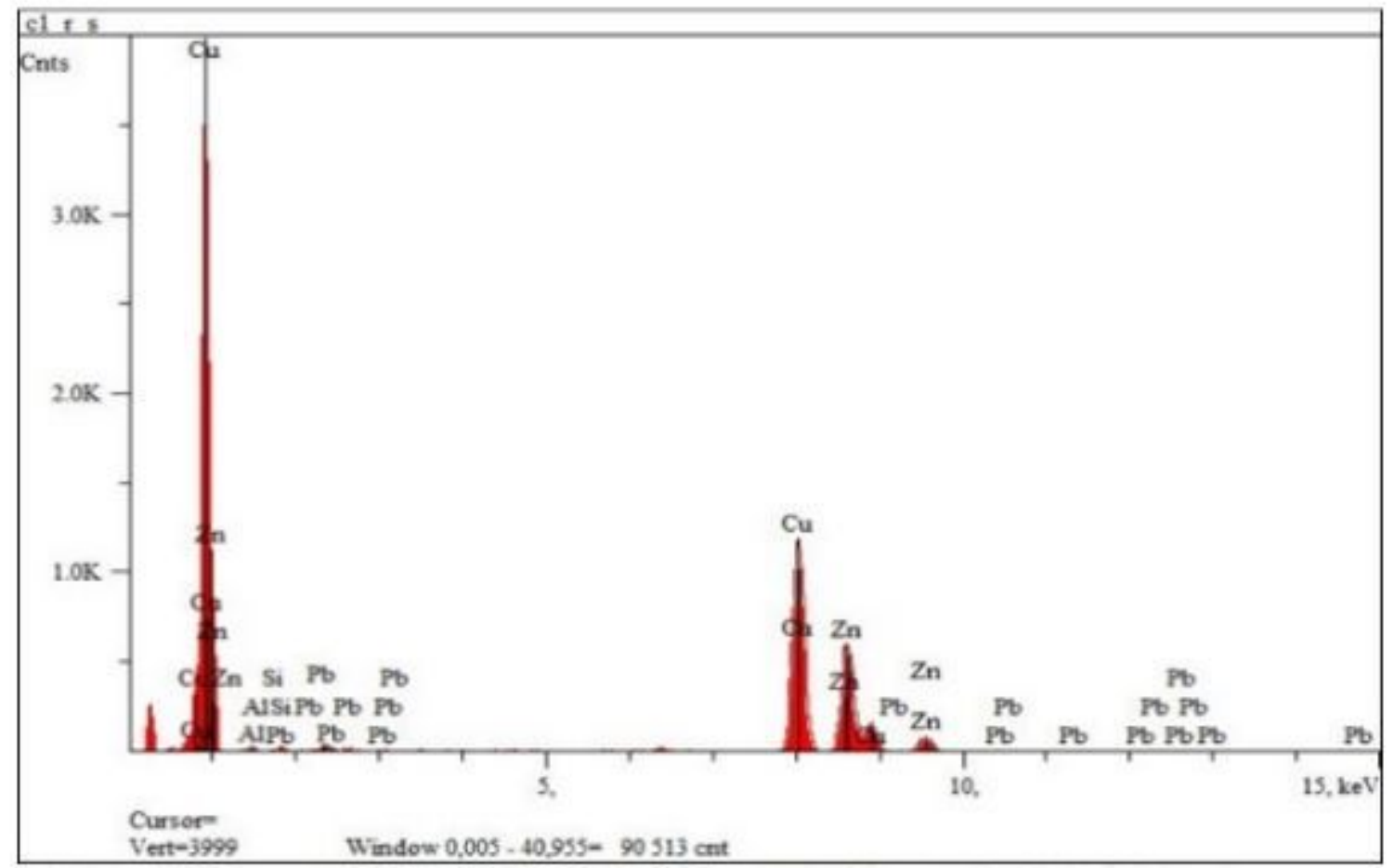

E1t. Line Intensity Conc Units Error MDL (c/s) 2-sig 3-sig

$\begin{array}{llrrrrr}\text { Al } & \mathrm{Ka} & 2,50 & 0,522 & \text { wt. } \% & 0,138 & 0,190 \\ \mathrm{Si} & \mathrm{Ka} & 1,61 & 0,262 & \text { wt. } \% & 0,112 & 0,162 \\ \mathrm{Cu} & \mathrm{Ka} & 163,39 & 58,688 & \text { wt. } \% & 0,871 & 0,362 \\ \mathrm{Zn} & \mathrm{Ka} & 84,65 & 37,291 & \text { wt. } \% & 0,795 & 0,446 \\ \mathrm{~Pb} & \mathrm{La} & 0,80 & 3,238 & \text { wt. } \% & 1,985 & 2,866 \\ & & & 100,000 & \text { wt. } \% & & \end{array}$

$\mathrm{kV} \quad 20,0$

Takeoff Angle $\quad 35,0^{\circ}$

Elapsed Livetime 120,0

Figure 11

Analysis of the chemical composition of the sample from smelt $0.15 \%$ flux, zone 3 
3,00

2,50

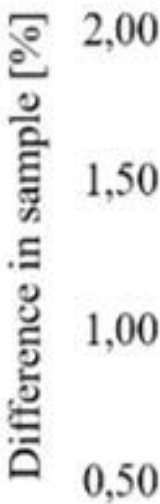

0,00

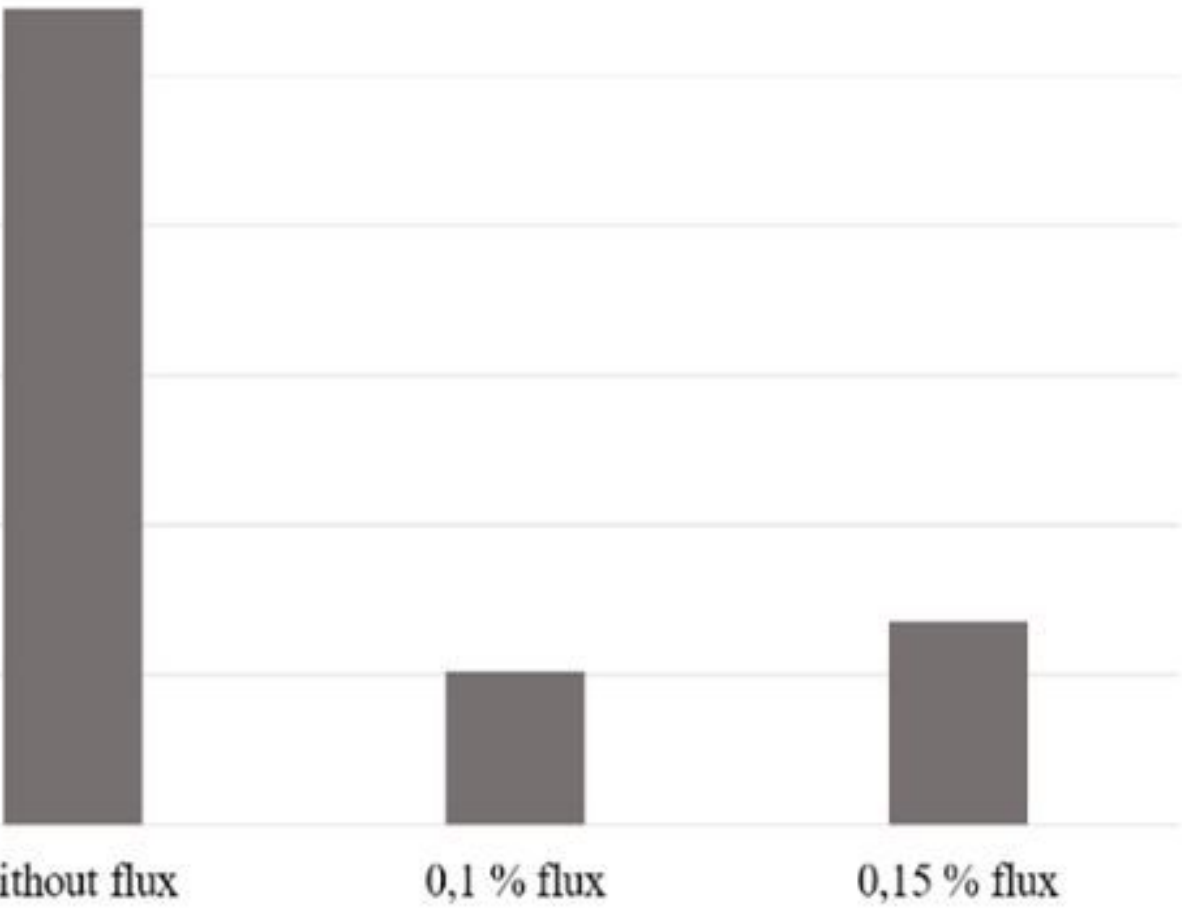

Figure 12

The percentage difference in the elements $\mathrm{Cu}$ in the samples examined 


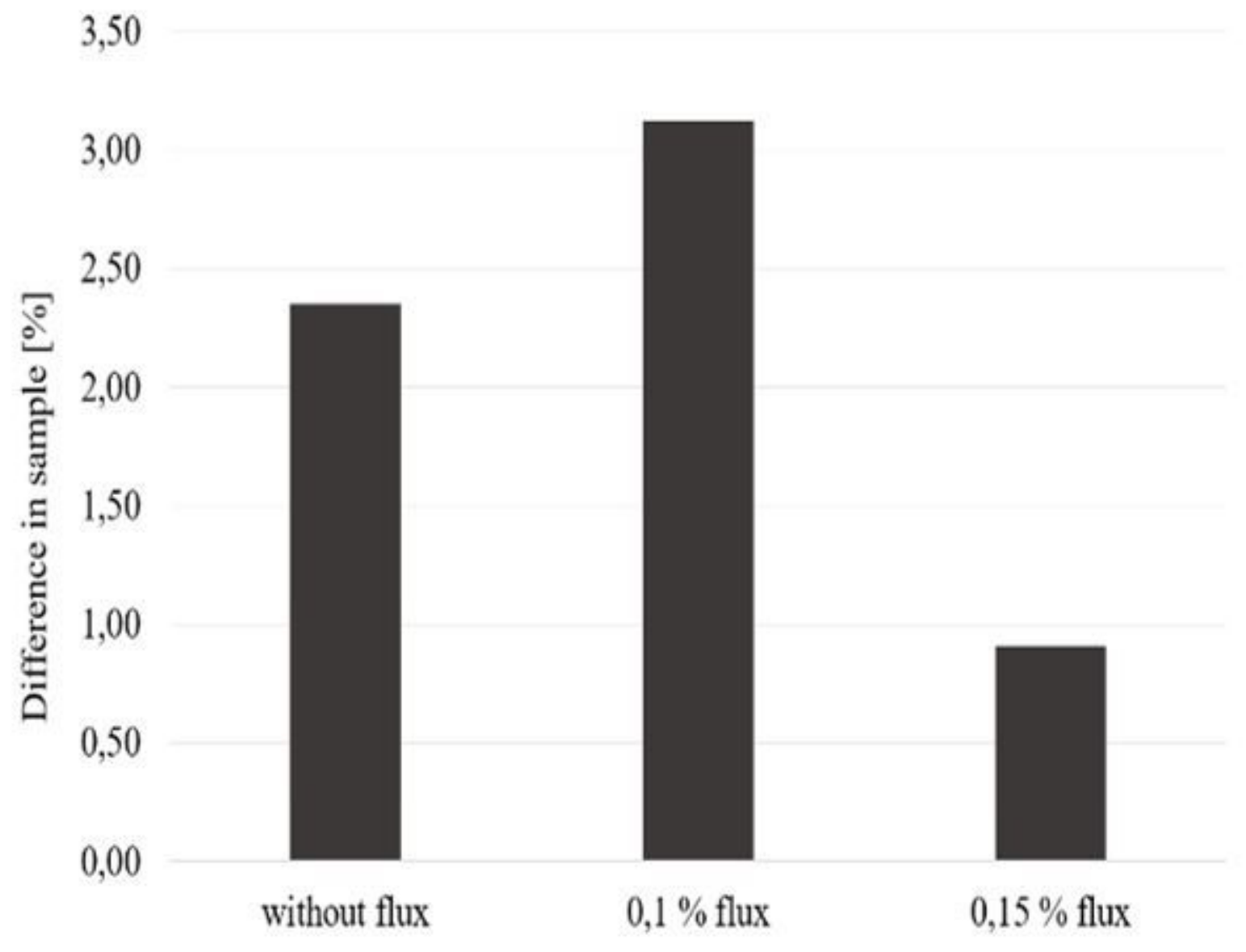

Figure 13

The percentage difference in the elements $\mathrm{Zn}$ in the samples examined 


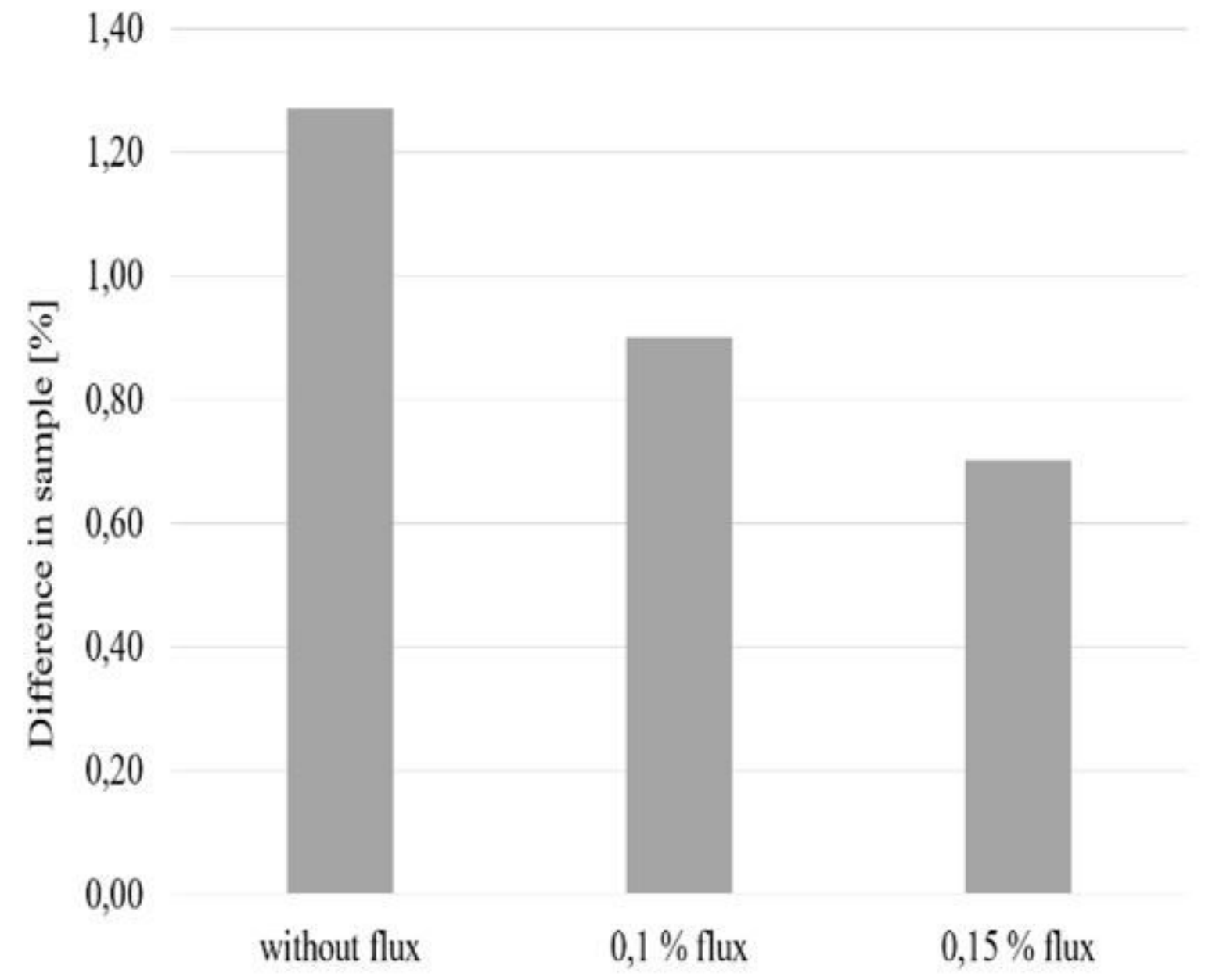

Figure 14

The percentage difference in the elements $\mathrm{Pb}$ in the samples examined 


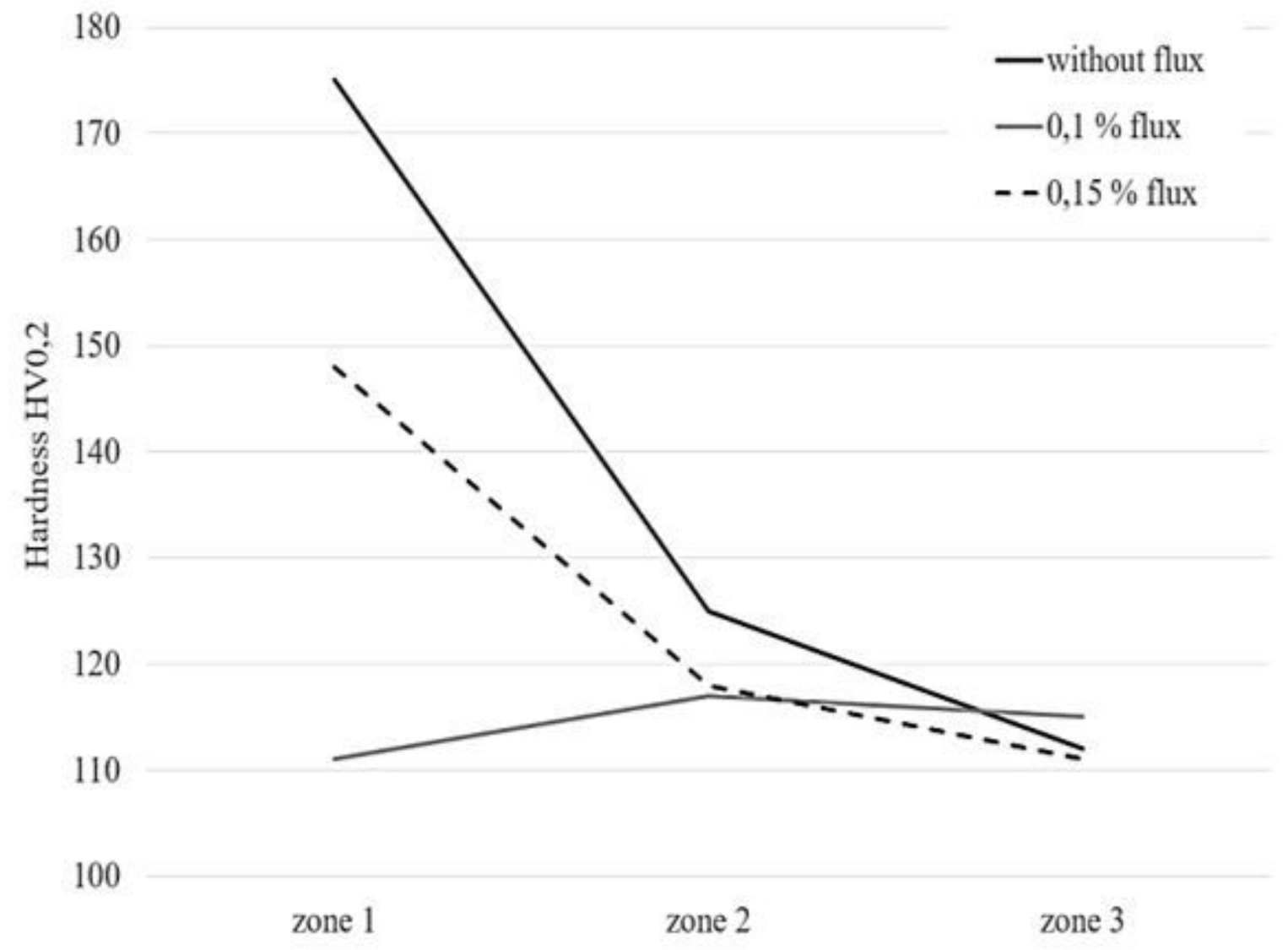

Figure 15

The results of measuring the hardness of the samples from particular zones, depending on the smelting conditions 
60

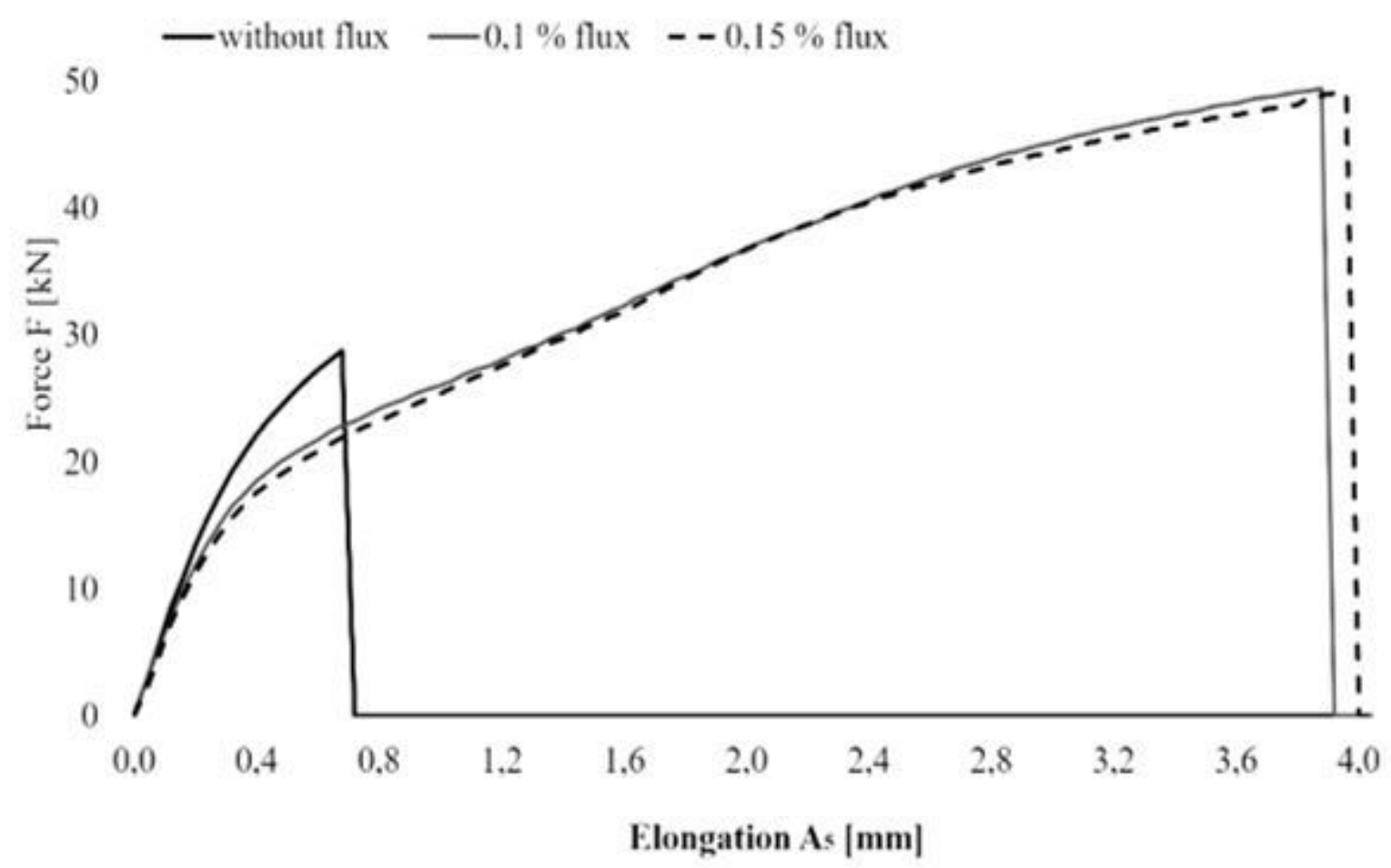

Figure 16

The results of the strength tests for the samples from particular smelts 